\title{
発見的逐次改良による最小費用流探索手法と 製鋼工場操業計画への応用 ${ }^{\dagger}$
}

\author{
高 橋 哲 也* - 小 西 正 躬* \\ 花岡, 宏 卓**.中川浩 之**

\section{Scheduling for Steelmaking Process Based on Minimal Cost Search Using Heuristic Modification Approach}

\author{
Tetsuya TAKAHASHI*, Masami KONISHI*, \\ Hirotaka HANAOKA ** and Hiroyuki NAKAGAWA**
}

\begin{abstract}
A scheduling method has been developed for steelmaking process, in which the problem is formulated in the minimum cost flow problem and the solution is decided using the sequential search approach. Sequential search algorithm is one of the well-known optimization method, but it often results in local optimization. Above all, for an integer problem as scheduling, which has a complex discrete structure, a sequential search approach is not available in many cases. To cope with this difficulty such methods as simulated-annealing and genetic algorithm are recently attempted, but the processing time should be much shorter for some actual application.

On the other hand, in the development of the actual application systems, it is often effective to utilize heuristics and to find a feasible semi-optimal solution. In this paper, a new method is proposed which contains heuristic rules in the process of sequential search. Many heuristic neighborhoods are defined in the form of flow modification patterns, and are selected to modify the network flow using heuristics of finding a good solution in the proper scheduling problem. The developed method was applied to the scheduling system in a steel plant, and the effectiveness of this approach was revealed in the actual application.
\end{abstract}

Key Words : scheduling, steel-making, sequential search, minimum cost flow problem, heuristics

\section{1. まえがき}

製造業における生産現場では, 多品種少量生産や製品 品質高級化の傾向を背景として, 工場内での物流が非常 に複雑になっている。このため, 操業者が行う計画作成 作業の負荷が大きく, 計算機による計画作成支援のニー ズが強い.このような実操業のシステムでは, 短時間に 適正な計画を作成することが要求されるが，現在のとこ

†第 28 回自動制御連合講演会で発表 $(1985 ・ 11)$

* (株) 神戸製鋼所電子技術研究所 神戸市西区高塚台 $1-5-5$

** (株) 神戸製鋼所神戸製鉄所 神戸市灘区灘浜東町 2

* Electronics Research Lab., Kobe Steel, Kobe

** Kobe Works, Kobe Steel, Kobe

(Received May 27, 1992)

(Revised November 10, 1992)
ろ一般に有効な手法は確立されていない。そこで本論文 では, 最適化アルゴリズムの中に操業計画のヒューリス ティックスを組み込むことにより実用的に計画作成する 手法を考案し，実際に製鋼工程の操業計画システムに適 用したので，その内容について述べる11,2).

実際の製造業における操業計画システムに扔いては， たとえばコスト最小化やリードタイム短縮などといっ た，計画に対する最適性が多くの場合に要求される。し かし, 最適化計算は膨大な計算時間を要するため, 実用 的な時間で解を求めることは困難である。そのため従来 の実用システムでは，ヒューリスティックスを利用して 解を求める方法や，シミュレーションなどを用いて操業 者との対話で計画を作成することが多く，エキスパー ト・システムの応用例などがいくつか報告されてい る) 
しかし,ヒューリスティックスのみに基づく方法では, 解の最適性に対する保証はなく, 実用的な計算時間とひ きかえに最適解の追求をあきらめているのが現状といえ る.そこで本研究では, 数理計画における最適化のアル ゴリズムにヒューリスティックスを融合することにより 両者の問題点を補完し, 最適化を指向すると同時に短時 間で解を求める手法の開発を目的とした。

最近, 同様に操業計画の問題に対して AI 手法と数理 計画手法を組み合せる試みがほかにも見受けられる。た とえば，七ューリスティックスを分枝限定法の効率化に 用いる試み ${ }^{7)}$, 問題を大局的判断と局所的探索に分割し てヒューリスティックスと最適化手法を使い分ける試 み ${ }^{8)}$, 段階的な制約充足の過程でヒューリスティックス と最適化手法を併用する試み9)などが報告されている. しかし, それらのすべては計画を組み合せ最適化問題と して捉え, 解を絞り込む過程に重点が置かれている. ころが実際の操業計画の専門家は, かならずしも計画作 成を組み合せ最適化問題として捉えているとは限らな い.むしろ, 計画全体を俯瞰的に眺めながら, 暫定解へ の試行錯誤による修正を繰り返す場合が多い。つまり, そのような専門家は逐次改長のノウハウを保有している といえる. そこで, 本論文では従来報告されている方法 と異なり, 逐次改良による解探索の過程にヒューリス ティックスを導入する手法を試みた。ここで開発した手 法では対象となる製鉄所の操業計画の問題を最小費用流 問題で定式化することにより，より直接的に最適化の問 題として扱うアプローチを行った．また短時間で適正な 解を求めるために, 解の探索を逐次改良型のロジックで 行い, 探索の過程に計画作成ノウハウを組み込む手法を
考案した。これにより，実際のシステムへの適用におい ても実用的な手法とすることができたので，その内容を 以下に述べる.

\section{2. 対象プロセス}

Fig. 1 に, 計画の対象である溶銑処理工程のレイアウ トを示す．この工程は, 高炉で生産された溶銑が台車で 運ばれて製鋼工場に到着してから転炉で精錬されるまで に，脱硫や脱燐などの溶銑処理を行う工程である．溶銑 処理のための設備としては溶銑処理炉と取鍋脱硫設備が あり，設備間の搬送は 2 機のクレーンが行う。一つの溶 銑鍋にはいった溶銑をチャージと呼び，処理や搬送は チャージ単位で行われる.

クレーン A は到着した溶銑鍋を溶銑処理設備に搬送 する目的で使用され,クレーン B は溶銑を転炉に搬送す る. 溶銑処理炉に溶銑を入れたあとの空鍋は, そのまま クレーンA でもとの台車に戻される.転炉に溶銑を運ん だあとの空鍋は, 同様にクレーン B で戻される.クレー ン $\mathrm{A}, \mathrm{B}$ は同じ軌道上にあり, 両クレーンの位置関係は 逆転させることができないため, クレーンによる搬送処 理は互いに干渉しあう。また，溶銑処理炉での作業とク レーン作業の干渉なども存在し, 種々の操業上の制約が ある・

この工程内での各チャージの処理ルートには, Fig. 2 で示すようなものがある. 図のいちばん上のルートは溶 銑処理炉で脱燐・脱硫の両方もしくは片方だけが施され るルート，つぎが取鍋脱硫されるルートであり，いちば ん下は何も処理されずに転炉へ直送されるルートであ る、各チャージの鋼種(製品の種別)によって望ましい処

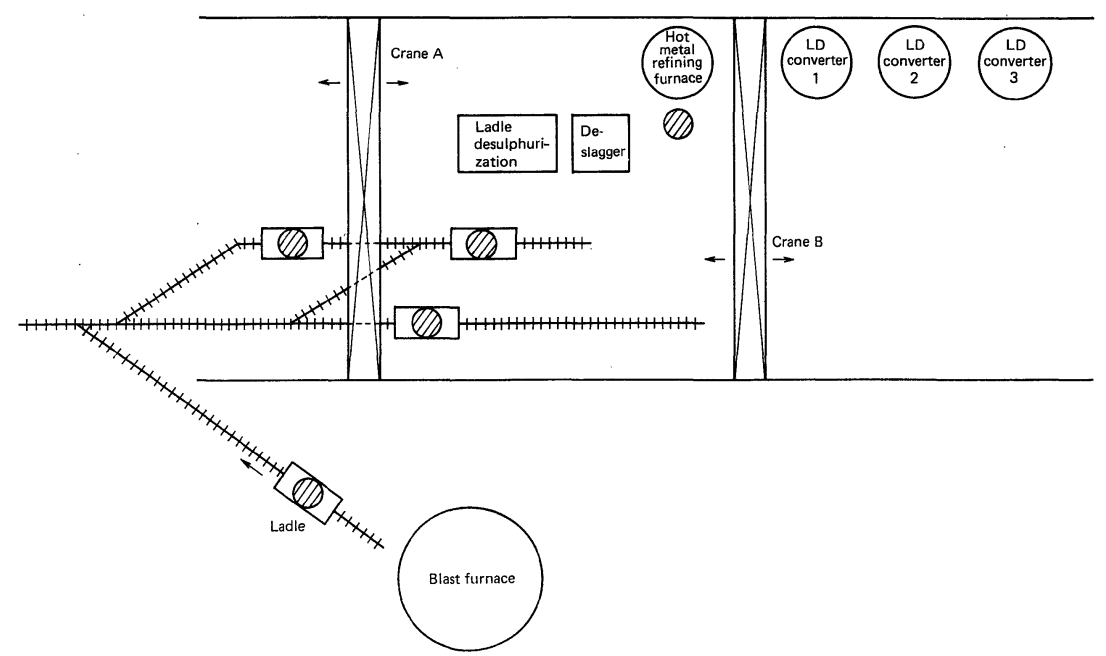

Fig. 1 Hot metal process 


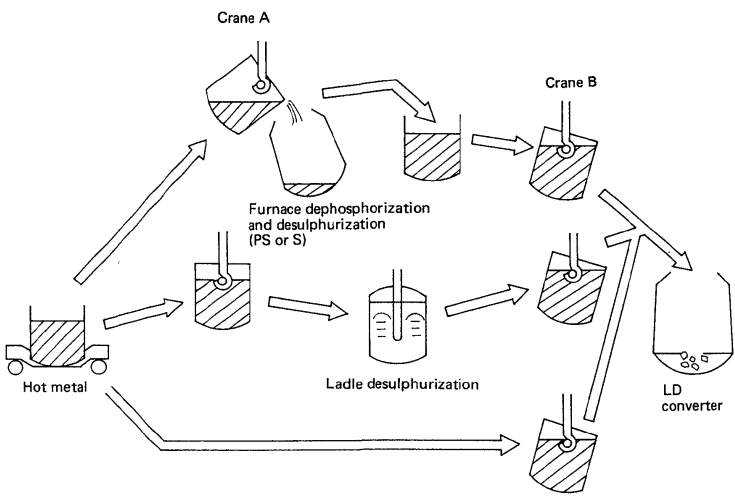

Fig. 2 Processing route

理ルートは決まっているが，望ましいルートを通らなけ れば生産コストが高くなる。

各チャージが工場に到着する時刻は予定として与えら れており，また生産計画より転炉での溶銑要求時刻も与 えられる．途中工程の溶銑処理時間などは，鋼種に応じ て定まっている。

以上より，この対象に対する計画の問題は，各チャー ジの処理ルート決定と，処理や搬送の時刻決定を行う問 題として扱われる。計画作成の際におもに考慮すべき点 には，以下のようなものがある。

- 各チャージに対する処理は，対応する溶銑鍋が到着 してから，転炉での要求時刻までの間に行わなければ ならない.

- 溶銑処理の能力やクレーン作業の干渉などによる， 制約条件を満足しなければならない。

- 製造コストなどの評価関数が，最良となる計画が望 ましい。

\section{3. 最小費用流問題による問題の定式化}

\section{1 ネットワーク流による溶銑物流の表現}

この問題を，ネットワーク計画における最小費用流問 題としてモデル化した。

まず,この工程内での各溶銑の物流は, Fig. 3 に示すよ うなネットワークで表現できる.このネットワーク上で, 横方向の流れは時間経過を表わし, 繸方向の動きは工程 の進行を表わす.このネットワーク中には，l=1〜12で 示してある 12 種類の有向枝が存在し, それらは溶銑処理 の工程進捗状況に対応する.たとえば, $l$ が 1 から 5 まで の真横に向かう枝は溶銑が何も処理されずに工程内に滞 留していることに対応し，そのほかの右下への枝は所定 の所要時間 $T_{6} \sim T_{12}$ によって処理や搬送がされている 状態に対応する，各枝は，計画作成の精度の時間刻みで

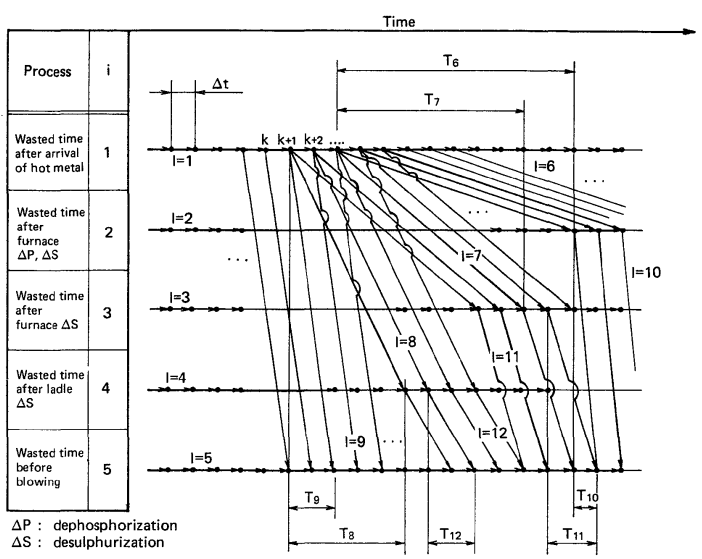

Fig. 3 Network model

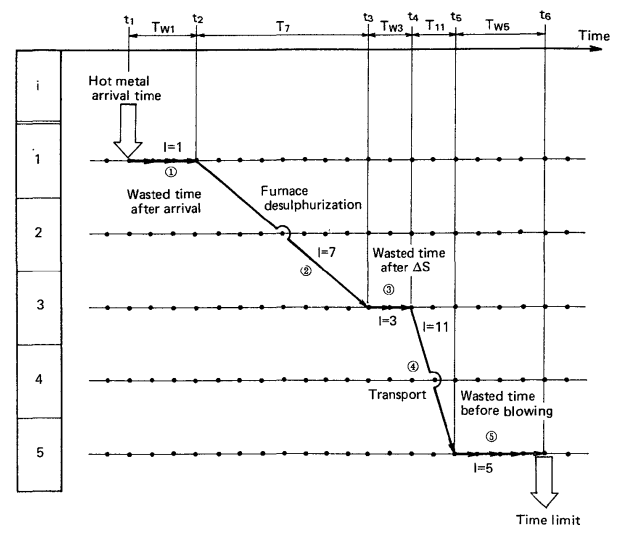

Fig.4 Network flow representation

設けられており，この精度内での各溶銑の挙動は, すべ てこのネットワーク上での流れとして表現できる.

Fig. 4 には，1 チャージ分の溶銑の動きをネットワー ク流で表わした例が示してある。この流れを実際の操業 に対応させると，時刻 $t_{1}$ に工場に到着した溶銑が，時刻 $t_{2}$ に溶銑処理炬に搬送され, 脱硫処理されたのちに時刻 $t_{5}$ に転炉に到着し, 要求時刻 $t_{6}$ に間にあっていることを 意味する、したがって，各チャージに対してこのような 流れを設定することにより，この問題に対する解として， 各溶銑の処理ルートとタイム・スケジュールが同時に決 定できることになる.

\section{2 コストの定義}

ネットワークの各枝には，その枝に対応する処理のコ ストを定義し，枝を通る流れに対してコストを課すこと ができる.たとえば, $l=1 \sim 5$ の枝のコストは, 各工程で 単位時間あたりの溶銑滞留によって発生する熱損失など に対応する．また， $l=6 〜 12$ のコストは，各溶銑がそれ 
らの工程を通過した際の処理コストに対応する。これを 定式化すると以下のようになる.

ネットワークの各枝に流れが存在するかどうかを表わ す変数を $X(k, l, n)$ とする.これは, チャージ $n$ に対応 する流れが, 時刻 $k$ の枝 $l$ に存在する場合には 1 , 存在 しなければ 0 となる変数とする。これに対し，チャージ $n$ に対する枝 $l$ のコストを $C_{0}(l, n)$ とすると, 処理コス トの総和はつぎの $J_{0}$ になる。

$$
J_{0}=\sum_{n} \sum_{l} \sum_{k} C_{0}(l, n) \cdot X(k, l, n)
$$

さらに，チャージどうしの処理の干渉などによって生 じる制約条件も，コストで定義した。この問題における 操業制約のほとんどは,「ある枝に流れが存在する場合に は，特定範囲内の枝をほかのチャージの流れが通っては いけない」という形で表現できる. Fig. 5 には，そのよう な制約条件の例を示しており，太線矢印の枝に流れが存 在すると，斜線の範囲の枝を流れるほかのチャージに対 して大きなぺナルティ・コストを課すことを意味してい る.たとえばFig. 5 (a) は, 同一時刻に複数のチャージが 溶銑処理設備を共有できない制約を表わす。また（b) は，溶銑処理炉で処理を行う際に，搬送設備との干渉に より，ある範囲の時間はほかの溶銑を転炉に搬送できな いことを表わしている.ここでは，斜線範囲の内側に入 るほど, コストが急激に増加するように設定されている。

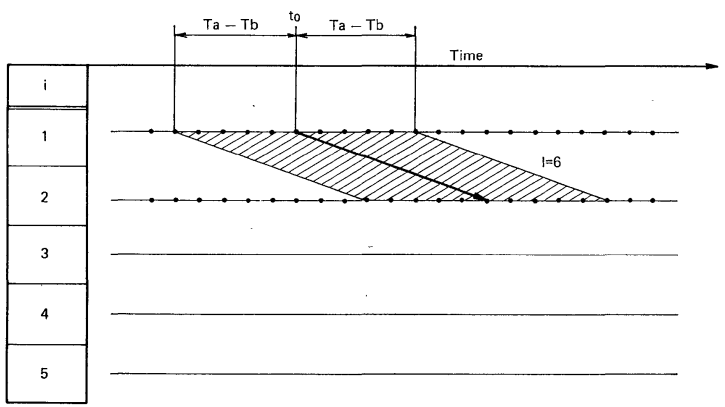

(a) Occupation of machine

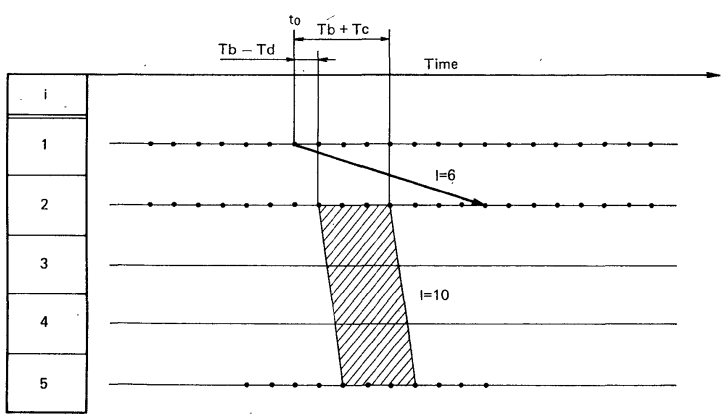

(b) Interaction between operations

Fig. 5 Examples of restriction
この問題では, (a )のような溶銑処理炉・取鍋脱硫設備・ クレーンなどの設備占有に関する制約と，（b ）のような クレーン間の差し合い・クレーン動作と他作業との干渉 に関する制約などを Fig. 5 のようなペナルティ・コスト のパターンで約 40 個定義した. また，それらの制約すべ てに対して，ここではFig. 6 に示すようなペナルティコ ストを設定した．図中の $K_{1} \sim K_{2}$ はペナルティを課すべ き相対時刻の範囲を表わし，縦軸はその時刻の枝に発生 するコストである.つまり, Fig. 5 で示した斜線の内側に 入るほど大きな操業上の支障となるので, 急激に(ここて は 2 次のオーダで) コストが増加するようにしてある.図 中の $\mathrm{G}$ には, 通常のコスト $C_{0}(l, n)$ と比較して十分に大 きな值を設定した。

このようなパターンの定義により，時刻 $k$ の枝 $l$ に チャージnの流れが存在した場合に, ほかのチャージ $n^{\prime}$ に対する時刻 $k+\Delta k$ の枝 $l^{\prime}$ におけるぺナルティ・コス ト $C_{1}\left(\Delta k, l, l^{\prime}, n, n^{\prime}\right)$ が設定できる.したがって, ペナル ティ・コストの総和は以下の $J_{1}$ になる.

$$
\begin{aligned}
J_{1}= & \sum_{(k, l, n)} \sum_{\left(k^{\prime}, l^{\prime}, n^{\prime}\right)}\left\{C_{1}\left(k^{\prime}-k, l, l^{\prime}, n, n^{\prime}\right)\right. \\
& \left.\times X(k, l, n) \cdot X\left(k^{\prime}, l^{\prime}, n^{\prime}\right)\right\}
\end{aligned}
$$

以上のように, 本問題は $J_{0}+J_{1}$ を最小にするように, 各チャージの操業に対応するネットワーク流を決定する ことに帰着する.したがって，処理ルート選択や処理時 刻決定，および干渉などの制約回避といった，問題に含 まれる要因のすべてを，最小費用流問題として統一的に 定式化できたといえる。しかし，この定式化では，時刻 $k$ の刻みを 1 分の精度としても， 8 時間・約 16 チャージ 分の計画を考えると，9万個以上の 0-1 変数からなる整 数計画問題となり, 列挙的な方法で最適解をもとめるこ とは困難である，そこで，この定式化のもとで発見的な 逐次改良を行い，短時間で有効な解を求める手法を開発 したのでつぎに述べる.

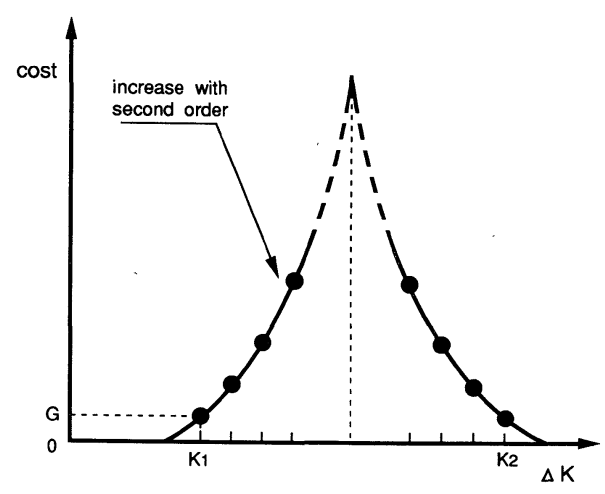

Fig. 6 Penalty Costs 


\section{4. 発見的逐次改良による溶銑処理計画の作成}

\section{1 発見的近傍}

逐次改良法は最適化アルゴリズムとしては一般的であ るが, 多峰性の問題を扱うと局所最適解しか得られない ことはよく知られている。とくに，スケジューリングに 代表されるような整数計画問題では, 問題自体が複雑な 離散構造で多くの局所解が存在するため, 満足な結果が 得られる例はまれである。最近ではその問題を回避する ために，シミュレーティド・アニーリング法や遺伝的ア ルゴリズムなどの手法を用いる試みがあるが(10) 12), 対話 型システムへの適用などの即応性を要求される場合に は，さらに計算時間の短縮が必要である。そこで，操業 にとって不適切な局所解を避けて適正な解を短時間で求 めるために，逐次改良の過程にヒューリスティックを導 入することを考察する。

整数計画問題に対して逐次改良型アルゴリズムを適用 することが困難な理由の一つに, 解空間での距離の定義 が不明確であることがある。連続系のように空間がなめ らかな場合には, 近傍を探索しながら解を改良する方法 がよく用いられるが，整数問題では近傍も一般的に定義 しにくい.むしろ，スケジューリングなどの整数計画問
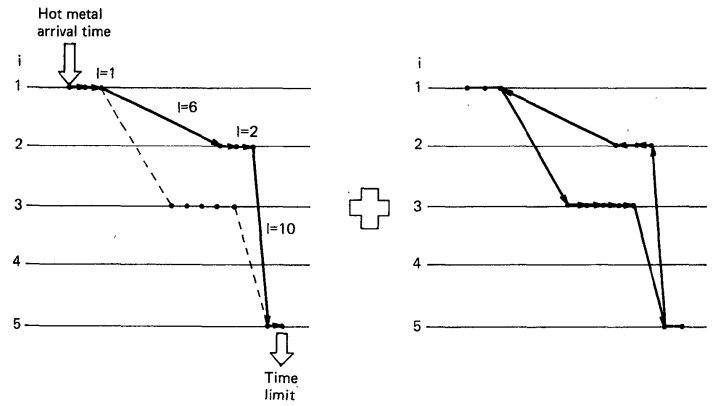

(a) Flow before modification (b) Loop for modification

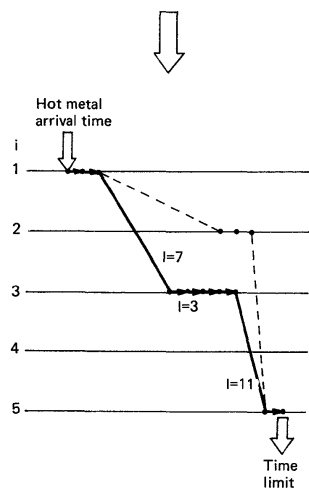

(c) Flow after modification

Fig. 7 Network flow modification
題における近傍は，問題固有のヒューリスティックスに よって定義すべきものである。

そこで，さきに定式化したネットワーク流における近 傍を定義することを考える．たとえば Fig. 7 (a)の流れ を（c）に修正するには，（a）に対して枝の逆流を含む ループ状の流れ (b)を加えればよい。これにより，ルー プの負の流れの部分に起因していたコストは解消し，新 たに加わる正の流れに関わるコストが発生することにな る、つまり，近傍の定義はこのような流れのループのパ ターンとして定義することで可能である.Fig. 8 には, そ の例が示されている.（a）は，溶銑処理炉での処理時刻 を変える近傍の定義である．また $(\mathrm{b})$ は，溶銑処理炉で の脱燐・脱硫ルートを通るチャージを，脱硫処理のみの ルートに変更する近傍である。ここで定義したようなパ ターンは，数学的に厳密な意味での「近傍」とはいえな いが，概念的には近傍に類したものという意味で，あえ て発見的近傍と呼んでいる.溶銑処理計画の問題に対し ては，(a)のような処理時刻変更に関するパターンを約 50 通り用意した，また，（b）のような処理ルートの変更 パターンはルートの組合せ，およびルート変更後の処理 タイミングが異なるものを約 30 通り用意した.したがっ て本問題では合せて近傍を約 80 パターン用意した。

\section{2 ヒューリスティックスを用いた探索}

解の探索は Fig.9 のように，ネットワーク流修正パ ターンの中から選択し，解を修正していくことによって 行われる，ここで，選択すべき近傍を決定するための ヒューリスティックスを与えるために，定義されている 近傍パターンはグループ分けし，それぞれのグループに
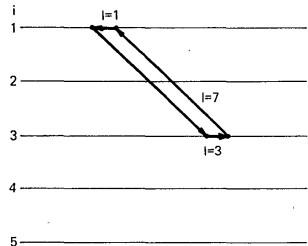

(a) Alternation of process time

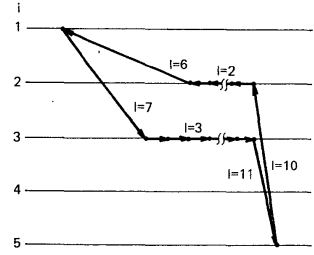

(b) Alternation of process route

Fig. 8 Examples of neghborhood 


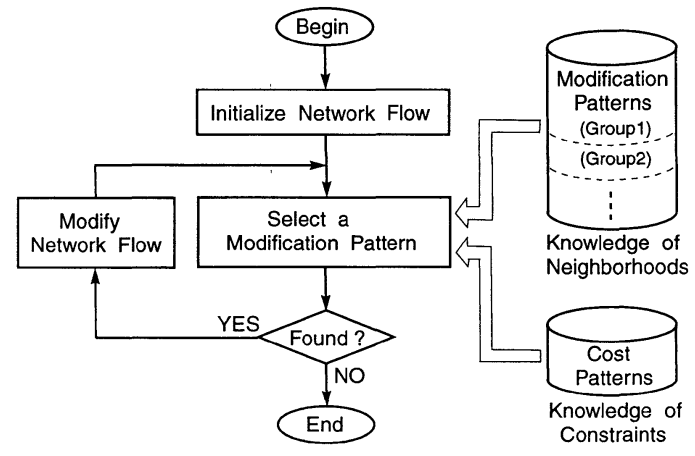

Fig. 9 Scheduling procedure

プライオリティを付けた。 また，修正パターンが選ばれ るための必要条件として, 修正により改善されるコスト の最低限界をあたえるものとした。つまり，修正パター ンの定義は

(グループID：プライオリティ

発火条件：コスト改善 $\geq$ 最低限界

修正パータン群:

$$
\{\text { パターン } 1, \text { パターン } 2, \cdots\})
$$

といった形でグループ化され，まずプライオリティ最高 のグループから近傍が探索される. 条件を満たす近傍が なかった場合にのみ, より低プライオリティの近傍が探 索され, 条件を満たす修正パターンがみつからなければ 探索を打ち切り，そのときの解を最終的な解とする。こ の方式によって与えられるヒューリスティックスは非常 に簡単なものであり, 今後より複雑なルールを記述でき るようにする必要があると考えられる.しかし, 今回対象 とした問題における, たとえば以下の $\mathrm{a}, \mathrm{b}$ のような操業 計画のノウハウを組み込むには十分であった.

a.「なるべく処理ルートは変更せず，

時刻変更のみで制約を回避したい」

b. 「溶銑処理が必要な鋼種は，なるべく

転炉へ直送するルートへは変更しない」

a を実現するには，大きなコスト改善最低限界を設定し た修理時刻修正の近傍群からなるグループを高プライオ リティにしておき，時刻変更で大きな改善が得られる場 合はほかのパターンが選ばれないようにすればよい.ま た b は，転炉直送ルートへ変更する近傍を低プライオリ ティにしておくことで実現できる.今回の問題では 7 個 のプライオリティをもつグループを定義した. 以下にそ れらのグループについて簡単に述べ，溶銑処理計画の問 題に組み込まれた計画ノウハウの概要を示す.

[プライオリティ1のグループ］

通常の鋼種において望ましいルート変更からなるグ

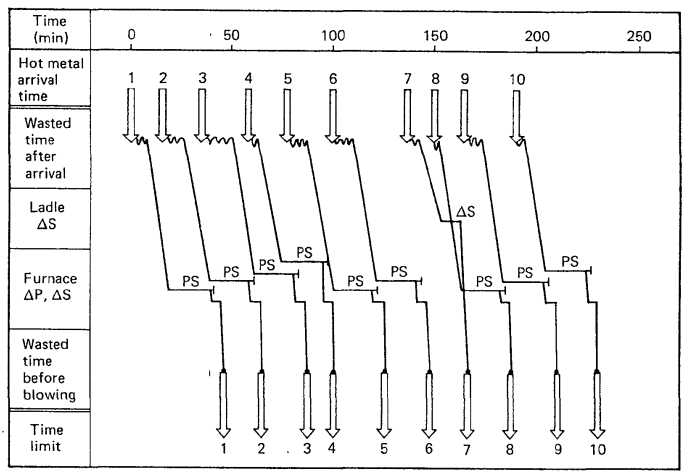

(a) Initial solution

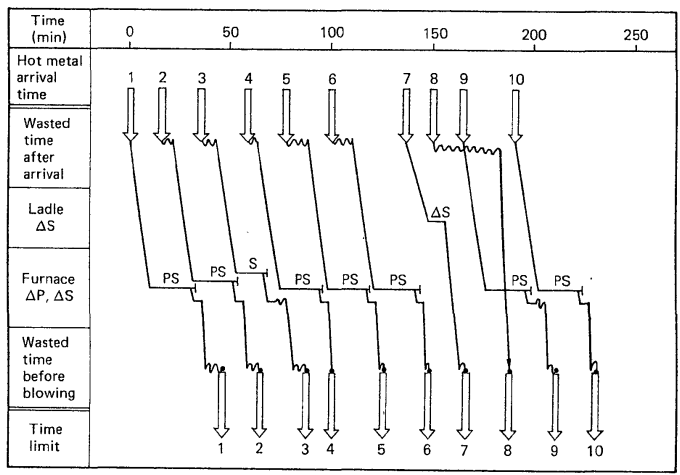

(b) Intermediate state of solution

Fig. 10 Process of search

ループ. たとえば「何も処理しないルートから何らかの 溶銑処理をするルートへの変更」や「脱硫処理のみのルー トから脱燐処理を行うルートへの変更」や「脱硫処理の みのルートから脱燐処理も行うルートへの変更」といっ た修正パターンが，このグループに含まれる。

[プライオリティ $2,3,4$ のグループ]

処理や搬送の時刻を変更する修正パターンからなるグ ループ. 解が制約条件を満たさない場合には, 処理ルー トを変更するよりも，まず時刻をずらすことにより対処 を試みるために高いプライオリティに位置している。こ れらの 3 個のグループ内では，たとえば溶銑処理炉など の操業ネックとなる処理の時刻修正パターンが高いプラ イオリティに置かれている.

[プライオリティ 5,6 のグループ $]$

プライオリティ 1 とは逆に処理を取りやめるルート変 更からなるグループ. プライオリティ 2 ～ 4 のグループか ら適当な修正パターンがみつからなかった場合には, 処 理ルートの変更により制約を満足させることが試みられ る.二つのグループ内では, 操業上あまり望ましくない 


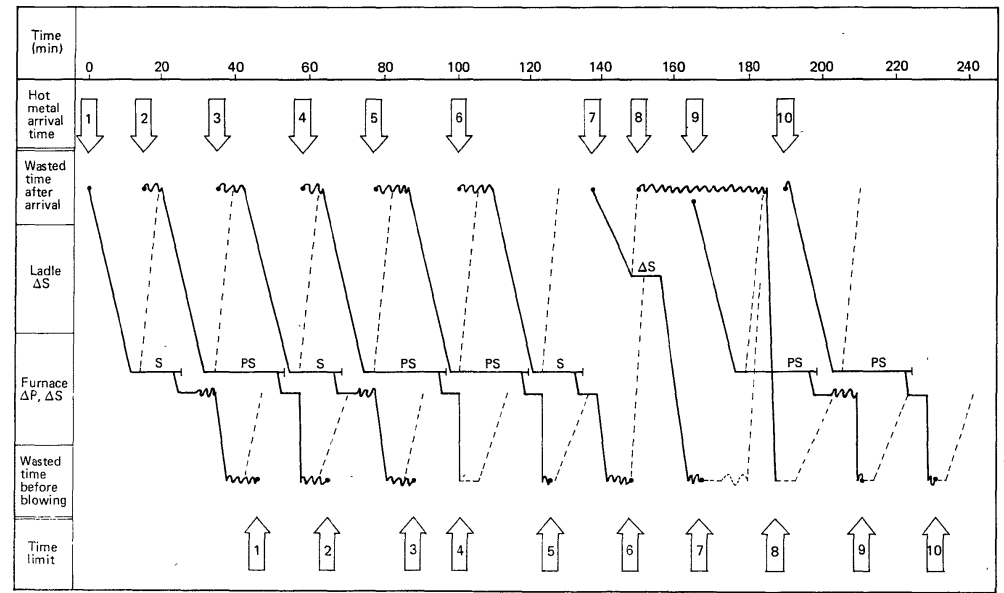

Fig. 11 Scheduling result

ルート変更は低プライオリティのグループに置かれる. [プライオリティ 7 のグループ]

処理・搬送時刻の微調整を行うグループ.これにより， 途中工程の滞留時間にかかわるコストを減少させる.

実際に Fig. 10 には，ヒューリスティックスを用いた 探索で解が改良されていく過程の例が示されている。わ かりやすくするために，ネットワーク流による表現では なく，実際の操業に対応した表現で表わしてある。図の 縦方向は対象プロセス内での工程であり，横方向は時刻 である. 図中の 1〜10 の矢印は, 10 チャージ分の溶銑の 到着予定時刻と転炉での要求時刻である。また，その間 の実線は各チャージが途中工程に存在する時刻範囲を示 している. 図中の $P S$ や $S$ は溶銑処理炬における脱燐・ 脱硫処理を表わし， $\Delta S$ は取鍋脱硫設備による脱硫を表 わす。波線は，チャージが何も処理されずに工程に滞留 している期間である。

Fig. 10（a ）は初期状態であり，転炉での期限に間に合 う処理ルートのうち, 処理コスト最小のものを各チャー ジについて設定してある。（b）は逐次選択された修正パ ターンによって約 50 回の修正が行われたあとの状態で あり,同一設備が同時に複数チャージに使用されるなど, チャージ間の干渉が解消できていないのがわかる。この 探索の結果, 約 65 回の修正後に Fig. 11 のような最終解 がえられた。この図には，破線で 2 機のクレーンの動き も示してあり，クレーンどうしの干渉などの，搬送設備 の制約も満たされていることがわかる。

\section{5. 評価と考察}

ここで開発した手法は，実際の製鉄所のスケジューリ ング・システムに適用されている，前述したような発見
的近傍と探索のヒューリスティックスを組み込むことに より,最終的には約 8 時間分の 16 チャージに対する操業 計画が約 20 秒で作成できるようになり,実用的な処理時 間で解が得られている。

実際のシステムに適用するに先立ち，実操業と同等な 条件で 25 通り約 300 チャージについてのケーススタ ディを行った結果，すべてのケースにおいて実行可能解 が得られた。また，各チャージに対して決定されたルー トのうち約 $94 \%$ がそれぞれのチャージの最も低コスト のルートが選択されており，十分に要求を満足する結果 となっている.システム稼働後の実績においても，途中 工程での滞留時間減少により溶銑温度降下が約 $17^{\circ} \mathrm{C}$ 減 少したと報告されており，この点でも操業コスト低減に 奇与している.

また，今回採用した定式化の利点として，制約条件を 満たす解が探索できなかった場合でも，操業上のアク ションを判断するうえで十分な情報を操業者に提供でき る点が挙げられる.たとえば，前に示した Fig. 10（b）の ような制約条件を満たさない局所解で収束したとして も，「解なし」という結果しか得られないよりは，はるか に操業者にとって有益である.このため, システム稼働 後の操業者の負荷が大幅に軽減され，操業上の判断を適 正に行えるようになったという評価を受けている。

いっぽう今回の応用によって，本手法の課題も明確と なった。たとえば，ここで定義した修正パターンの数は 約 80 個であり，筆者らが当初予想した数よりもかなり多 い. その原因は，局所解におちいる状況が多様であるた め，それらの局所解を避けるための近傍が増えてしまっ たためである。これは，問題が複雑になると，定義す心゙ き近傍の構造も複雑になることを意味する。いいかえれ 
ば，問題固有の構造を分析・整理して，近傍の設定を系 統的に行う手法が必要があるということであり，今後の 研究課題である。しかし，そのような課題の存在を認め た上でも, 本論文で示したように, 解探索の過程にヒュー リスティックスを組み込むためのモデル化と枠組み作り を行うことにより，操業ノウハウを採り入れた実用的口 ジックを容易に実現できるということは，応用システム の構築にとってはきわめて有用なことといえる。

\section{6. ま と め}

逐次改良型の最適化ロジックに対して，その近傍定義 や探索過程にヒューリスティックスを導入する手法を開 発した。このように, 数理計画的な最適化アルゴリズム とエキスパート・システム的なヒューリスティックスの 融合により，両者の欠点である処埋時間の膨大さと解の 最適性欠如を補完し，スケジューリングのような整数問 題に㧍いても適正な解を短時間で求めることのできる手 法となった。また，ここで開発した手法は製鉄所の操業 計画システムに適用され, その実用性をも確認すること ができた、今後, 残された課題である, 近傍定義を適切 に行うための問題分析方法の検討や，より複雑なヒュー リスティックスの導入を行うことにより，さらに手法の 有効性を高めることが期待できる。

\section{参 考 文 献}

1）高橋, 田村, 小西, 奥野：ネットワーク計画法による溶銑 処理計画，第 28 回自動制御連合講演会，397/398(1985)

2) T. Takahashi, et. al. : Scheduling for Steel Making Process Using Mathematical Programming Method, Proc. IFAC Symposium on Automation in Mining Mineral and Metal Processing, 129/134 (1989)

3) F. Farhoodi : A Knowledge-Based Approach to Dynamic Job-Shop Scheduling, Int. J. Computer Integrated Manufacturing, 3-2, 84/95 (1990)

4) M. Numao and S. Morishita: Cooperative Scheduling and Its Application to Steelmaking Processes, IEEE Transactions on Industrial Electronics, 38-2, 150/155 (1991)

5）森下, 沼尾, 戸沢：協調型スケジューリングによる製鋼工 程スケジューリング・エキスパートシステム, 人工知能学 会誌, 5-2, 184/193(1991)

6）鳩野, 山縣, 田村：ルールベースを用いたフレキシブル生 産システムのオンライン・スケジューリング，システム制 御情報学会誌, 4-9，375/381(1991)

7）福村, 佐能,山川：鋼材出荷計画エキスパートシステムと 分枝限定法, オペレーションズ・リサーチ，33-1，33/ 39 (1988)

8）関根, 竹中, 本田, 江原, 新井, 美濃 : 専門家モデルに基 づく生産スケジューリング・システム, 人工知能学会誌, 5-2, 194/202(1991)

9）伊東, 石塚, 原田, S. L. Chung, 圓川：制約階層型探索法
を用いた配船スケジューリングシステム，人工知能学会 誌，6-1，60/71(1991)

10) 須貝, 平田：組合せ最適化アルゴリズムとその応用, 計測 と制御，29-12，18/25(1990)

11) F. A. Ogbu, D. K. Smith: The Application of Simulated Annealing Algorithm to the Solution of the $\mathrm{n} / \mathrm{m} /$ Cmax Flowshop Problem, Computers Opns Res., 17-3, $243 / 253(1990)$

12）西川，玉置：ジョブショップ・スケジューリング問題に対 する遺伝アリゴリズムの一構成法, 計測自動制御学会論文 集，27-5，593/599(1991)

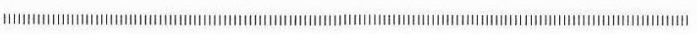

\section{[著 者 紹 介]}

\section{高 橋 哲 也(正会員)}

1983 年, 東京大学大学院計数工学修士課 程修了. 同年(株)神戸製鋼所に入社. 浅田 研究所, 電子技術研究所を経て, 現在, ス タンフォード大学客員研究員. スケジュー リング, 知的情報処理システムの研究に従 事. システム制御情報学会, 情報処理学会 などの会員。

\section{小 西 正 躬 (正会員)}

1969 年, 京都大学大学院数理工学専攻修 士課程修了。同年(株)神戸製鋼所に入社. 中央研究所, 浅田研究所を経て, 現在, 電 子技術研究所副所長 (工学博士). プロセス 制御, 人工知能, 生産システム最適化の研 究に従事. 日本鉄鋼協会, 日本塑性加工学 会, 人工知能学会などの会員.

\section{花岡宏卓}

1982 年, 大阪大学大学院治金工学専攻修 士課程修了. 同年(株)神戸製鋼所に入社. 神戸製鉄所製鋼部を経て, 87 年より鉄粉製 造部で現在に至る。製鋼プロセスにおけ る省エネルギ，高効率操業技術の開発に従 事. 日本鉄鋼協会，粉体粉末治金協会など の会員.

\section{中川浩之}

1985 年, 神戸大学大学院システム工学科 卒業. 同年 (株)神戸製鋼所に入社。神戸製 鉄所技術部システム室にて製鉄所工程計画 システムの開発に従事. 日本鉄鋼協会の会 員.
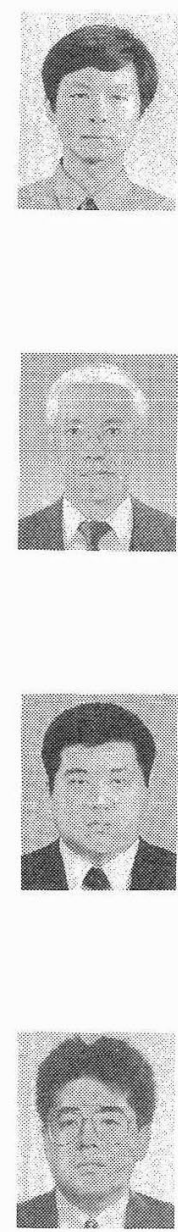

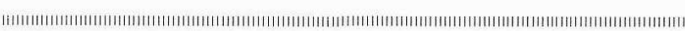

